\title{
2 Regional and Local Impacts
}

El activity has numerous and significant social, economic and environmental impacts on local communities throughout the project life cycle and after the closure of operations. The impacts are both positive and negative and are well documented. It is in the interests of all parties that steps are taken to avoid or mitigate the latter while maximising the former.

Some of the main potential benefits for local communities are employment, training and business opportunities. Other benefits come from the social investment programmes that El companies typically run in the areas of health and education, as well as support for cultural activities. Potentially negative impacts which require careful oversight include: resettlement of people living on top of natural resource deposits (which should be undertaken with reference to the World Bank's resettlement policy); respect for cultural artefacts; and cultural awareness training for mine staff.

Community development programmes differ in their rigour and quality and companies can be encouraged by governments to strive for established good practice as defined by international benchmarks. Emerging good practice is to plan and undertake community development initiatives in partnership with local communities, local government agencies, NGOs and academic institutions such as technical colleges. Implementing this work in partnership reduces the risk that the company will become a surrogate government agency, as well as helping to build the capacity of local government agencies to ensure that they can provide the services directly in the long-term.

More and more legislation is designed to take into account not only direct environmental impacts but also social impacts of industrial and other commercial projects. Accordingly, the arrangements can be used to safeguard local community interests by obtaining commitments from El companies that can be monitored and, if necessary, enforced.

The rest of this section considers in more detail the main socio-economic issues relating to El activity.

\section{Employment and training}

El activity can generate jobs, which in turn can raise household incomes and help lift people out of poverty. Though large-scale mechanised operations do not, generally speaking, offer direct employment to large numbers, they do offer skilled employment opportunities over relatively long periods. The relatively large numbers employed during the construction phase of projects can be high, but such work is short-lived and offers few opportunities for skills development. Often, far more significant economic opportunities emerge indirectly as a result of the demands for goods and services made 
by the El company. This phenomenon is discussed more fully in the 'local procurement' section that follows.

There are three other sources of jobs that may be provided by large-scale El companies. One set of jobs is created by the expenditure of El salaries (which tend to be higher than average) locally, stimulating demand for higher-quality goods and services. A second set of jobs can be created as a result of social investment projects undertaken by El companies. For example if an El company provides some of the funding to build or upgrade a local school or hospital, this will create temporary construction work as well as potentially permanent opportunities for education or health professionals. Finally, El companies may invest in enterprise development initiatives as part of their community development programmes. Such initiatives typically involve providing start-up capital and/or skills training to community groups and fledgling enterprises in order to either establish or grow a small business.

One additional, and often significant, source of employment connected with the mining sector is artisanal and small-scale mining (ASM). The arrival of large-scale operations may, if not carefully managed, usurp local operators, threatening jobs and leading to instability and conflict. There is not space in this paper to discuss this issue in detail, however there is emerging evidence that large-scale mining and ASM can successfully co-exist ${ }^{11}$, leading to better quality jobs in the ASM sector (which is typically informal and unregulated), a higher tax take for governments (due to the formalisation of the sector), and associated socio-economic development benefits.

Governments of resource-rich countries have an interest in ensuring that El activity maximises job creation opportunities. There are a number of measures that can be taken to this end. These are widely used and ought not to come as a surprise to experienced and responsible El companies.

Companies can be required to provide employment preference to qualified local citizens over foreigners. Hence sector policy should seek to encourage El companies to have in place plans for the employment of local citizens. In keeping with standard practice provision can be made in the El legislation and in the agreements signed with companies that require companies to demonstrate their plans for local employment and training when applying for natural resource rights. These plans can be developed in consultation with relevant arms of government, labour associations and community representatives. Training should be provided under an approved training programme.

A provision can also be included to require El companies to provide an agreed level of annual funding for technical knowledge and skills transfer to government officials in El-related disciplines. As a requirement for monitoring compliance, after operations have

11 See for example the work of the World Bank's 'Communities and Small-Scale Mining' (CASM) initiative. 
commenced, there should be a regular flow of information on employment and training activities and its outcomes, with reference to agreed performance measures.

In the case of artisanal and small-scale mining, there are opportunities for employment of large numbers of nationals.

\section{Local procurement}

The number of indirect jobs created by a large company's local procurement policy can be very significant. Not all a company's needs can be met locally, for example the huge tyres required on mining haul trucks are only produced by a handful of companies operating on an international basis. Nevertheless, there is a long list of goods and services required by modern extractive companies that can in theory be supplied by the local private sector including food and drink for the staff canteen, uniforms, maintenance of vehicles, equipment and civil works, roofing, carpeting, fencing, drainage, translation, transport, security, pest control, warehousing, tooling and telecoms.

In order to respond to this demand, small companies typically require access to credit, skills and knowledge so that they can meet the environmental, technical and quality standards required by El companies. The government can encourage El companies to form 'business linkages' with the local private sector, whereby skills, technology, and credit can be transferred from the large entity to the smaller one. The advantage of these linkages to the El company is that they can result in a more vibrant and competitive supplier base.

Legislation in this area might require El companies to procure equipment, material and services from local sources whenever items can be supplied that 1) meet the required quality standards, 2) are available at the time required and 3) are offered at prices that are competitive at the point of delivery. There may also be a provision requiring companies to facilitate the participation of local suppliers in the El supply chain by making requirements known from an early stage and providing guidance to potential suppliers on meeting the requirements. This objective should be incorporated as part of a business development programme that is broad enough to include more specialised goods and services. Such plans should be developed in consultation with relevant arms of government, business associations and community representatives. Once operations have commenced there should be a regular flow of information on procurement that has taken place and its outcomes, with reference to agreed performance measures.

Another form of government input that can help stimulate employment might be the establishment of a cluster of El companies and their suppliers to build the capacity of the smaller companies on a collective basis. This 'cluster' approach can be a costeffective intervention as it firstly enables El companies to indicate to local suppliers the quality standards required in order to access the extractive sector supply chain. Secondly it allows training and capacity programmes to be conducted on a collective basis, which is more cost-effective than working with lots of suppliers individually. Such 
cluster programmes have been successfully established in several countries including Chile, South Africa and Mozambique ${ }^{12}$.

\section{Refining, processing and consuming extractive products domestically}

An overwhelming percentage of the products of El activity are exported for processing, refining and consumption. As a result, some resource-rich countries seek further value addition opportunities in-country. However capitalising on these opportunities is not straightforward. The extractive sector produces highly standardised products, which implies very significant capital investment and training for internationally-oriented processing facilities. While there are advantages to having further processing and manufacturing activities occurring close to the extraction point, such as increased employment, skills development, backward and forward linkages and income generation, it may also make economic and logistical sense to perform further processing closer to markets. A case by case decision may be necessary.

There is scope in some countries to take advantage of downstream opportunities. The opportunities differ according to the product involved. For example the economics of minerals value addition will dictate whether or not a mining company is willing to invest in further treatment and processing of mined minerals at the mine site or within the borders of the host country. Key factors in this context include economies of scale, transportation costs, and the opportunities to take advantage of competitively priced inputs such as electricity. These factors tend to be site- and mineral-specific, so it is impossible to generalise across minerals. However one example from the diamond industry is as follows: before the fall in diamond demand in 2008, the government of Botswana had entered into an agreement with De Beers to construct an US\$80 million diamond processing plant in Botswana with the potential to create about 3,000 jobs and become the primary processing centre for De Beers diamonds mined in Botswana.

In the case of natural gas, the Tanzania case study on page 28 shows how locallyproduced gas is being used to produce electricity in-country. This approach can bring a wide range of socio-economic development benefits including increased access to energy for the region, a more attractive foreign investment destination, and even scope to export surplus power. The Tanzania example could be of particular interest for other gas-exporting regions where electricity supply is sporadic.

In the case of petroleum, a refining facility is necessary in order to add further value to the product. There are several factors that render local refining uneconomical. Refining activities are extremely capital-intensive and subject to important economies of scale. Over the past twenty years the refining industry has been extensively

12 UNECA and UNIDO are both undertaking ongoing work on clusters and linkages. See also the work of Antofagasta mining cluster. 
rationalised internationally, with the closure of most mid-scale refineries, along with the consolidation of production into large-scale refineries operating at 95 per cent capacity and above. Since a fully-fledged refinery is very expensive to build, it is difficult for a local refinery to be competitive unless very specific conditions exist.

There is scope, however, for the government to remove factors that could act as barriers to investment in value addition projects and, if considered economically justified (e.g. by creating jobs) and fiscally prudent, to offer financial incentives. This might include, for example, removal of certain tariffs and taxes, and infrastructure provision (see next section).

Fiscal concessions offered to add value to El products in-country should not be allowed to erode the extractive sector tax base. If companies set up value addition operations to take advantage of different and lower taxes from those that apply to El operations, the government must be vigilant in preventing companies from engaging in transfer pricing that would shift profits from the more taxed entity to the less taxed processing entity. In this regard, it is important that there is clear 'ring fencing' between an extraction business and a value addition (processing, refining etc.) business. 
CASE STUDY 3: Transforming the life of the local population using gas resources in Tanzania

Extracted resources are often exported for processing, refinement and consumption. Sometimes, an El project can positively transform the lives of the population of a producing region, by increasing energy availability, reliability and affordability. This in turn can lead to a wide range of socio-economic development benefits. Tanzania's Mnazi Bay/Mtwara Energy Project (MEP), through its integration of the entire value chain from the extraction of the gas through to electricity delivered to the customer, is a good example of this kind of project.

As in many developing countries, a small proportion (less than 20 per cent) of the population of Tanzania has access to a stable and affordable electricity supply. Approximately 85 per cent of primary energy supply is from biomass, with devastating impact on forests. The region of Mtwara is not connected to the main electricity transmission grid and therefore suffers more than most from energy poverty.

\section{Off-shore gas with no market}

The gas at Mnazi Bay was initially discovered in 1982 by AGIP, an Italian company. As years passed, the rights over the project changed hands a number of times with very little development taking place because of the same issue: there was no market for the gas. This was not a new problem. A core challenge for Tanzania's energy sector has always been access to market for commercialisation of hydrocarbon resources. The relatively small domestic market limits the volume of gas or liquids that can be absorbed locally, while the long distance to foreign markets has to date limited the possibility of exports.

\section{From extraction to consumption}

The solution was to integrate the whole value chain from gas extraction to power generation. Hence, in addition to gas extraction, the Mnazi Bay project included the construction of a gas processing facility at Msimbati Peninsula, a 25 kilometre marineland pipeline to the harbour town of Mtwara, and gas receiving facilities at the end of the pipeline. The construction of a 12MW power station was undertaken and on 23 December 2006 Mtwara received its first electricity supply generated from natural gas. Since that time, the town of Mtwara has received stable electric power - a claim that can be made by few towns in East Africa.

The Mtwara Energy Project (MEP) marks a number of firsts for Tanzania and for East Africa. It includes the negotiation of a transmission and distribution franchise covering the administrative districts of Lindi and Mtwara, where the delivery of power supply to residential, commercial and institutional customers will also be integrated. Before this project, the region had been subject to frequent blackouts. The project therefore also included an upgrade of the regional transmission and 
distribution system to link three isolated networks. In turn this means that the ageing, expensive and unreliable diesel fired generators could be closed down.

\section{Engine for economic development}

Although the region had an abundance of resources, market access potential and an underutilised labour force, the lack of a reliable and competitive electricity supply was a major impediment to the region's development. With the MEP, a major barrier to economic growth in the region was removed. The new power supply had an impact on the local infrastructure such as roads, schools and hospitals. Commercial and industrial interests are re-examining the region and re-assessing the potential of various economic activities including mining, forestry, agribusiness and manufacturing.

\section{Local benefits}

The growth in economic activity will take time to materialise. In the meantime, the daily life of the local population has already changed. Some have started to sell cold drinks, children are able to enjoy ice cream, and water authorities are able to guarantee steady water supply. Over the next 5-6 years, the plan is to have MEP connect electricity to some 46,000 householders in Lindi and Mtwara regions, improving the standard of living for citizens. With the increase in discovered domestic natural gas resources, the Government of Tanzania is giving serious consideration to establishing the country's first energy links into the broader East Africa region, setting the stage for Tanzania to become an energy exporter. Hence, with gas that nobody wanted and from a small $12 \mathrm{MW}$ power plant, there are now plans to construct a new power generation facility with a capacity of $300 \mathrm{MW}$ - produced at competitive cost, using the country's own resources.

\section{Infrastructure development}

Because of the scale and export-orientation of many El projects, their development often entails the building of new infrastructure. A world class project will require - and often be capable of meeting some of the costs of establishing - road and rail networks connecting it with markets, ports and harbours, power generation and supply lines and water supplies. Though constructed primarily to service the needs of a specific project or region, access to such infrastructure would ordinarily be available to the public (certainly roads, harbours and major electricity transmission lines) and regulated by the government. For example, one gas company in Egypt built a water supply pipe larger than required for its own needs, with the surplus water being used to supply communities along the pipeline route.

There is potential, therefore, for El activity to have a significant positive impact on a region's stock of infrastructure, providing a wider economic value not only in terms of 
facilitating investment by other businesses (taking advantage, for example, of deepened harbours and improved road access to the interior of the country) but also in terms of facilitating movement of goods, labour and power within the country.

A company may decide not to develop a region's natural resource deposits if there is inadequate infrastructure. In these circumstances it might be in the government's interest to contribute towards the costs of building infrastructure, particularly if such infrastructure were to have wider public use and if the government had access to concessional finance from international financing institutions. The government would be entitled to charge El companies for use of the infrastructure on an affordable cost-recovery basis. Such matters, being determined on a case-by-case basis, would need to be the subject of negotiated arrangements included in the El agreement and other contractual undertakings.

\section{Dispute resolution}

Because of the sheer complexity of extractive sector projects, and the size and range of impacts on local communities, it is common for differences of opinion to emerge between the company and a community. Sometimes these disputes can be resolved privately; in other cases tension may escalate and independent arbitration may be necessary..$^{13}$ Where a company has commenced activity in an area with complex and long-standing historical grievances that do not even relate to the current company's actions, the resulting dispute resolution process can be very complex to administer. Once again this highlights the importance of strong, independent institutions - in particular, in this case, the presence of a well-functioning judicial system.

\section{Employee rights and labour relations}

As with any other sector of the economy, El employment policy should seek to ensure that the development of the private sector takes place in a manner that respects the rights of employees in the workplace and the rights of other affected groups, in so far as their rights are enshrined in the laws of the country and any international obligations.

El legislation should be harmonised with other relevant legislation and international obligations and effective monitoring and enforcement of El company obligations should take place. The ministry responsible for the extractive sector should actively promote awareness of issues relating to employee and gender rights through dissemination of relevant information and the encouragement of initiatives that enable fruitful consultation to take place between stakeholders on these issues.

Employment issues that are particularly relevant to the extractive sector include terms of employment, working conditions, rights of employee association and collective bargaining. Legislation and regulations including those statutes regulating health and

13 Countries may want to refer to UNCITRAL rules. 
safety matters need to be in line with international provisions related to employment law and health and safety regulations. There should also be competent, independent enforcement entities with the authority to apply sanctions to non-compliant El activity, including in state-owned enterprises - again the necessary precondition of not only having proper frameworks but also appropriate institutions. Artisanal and small-scale mining, which can employ significant numbers in mining countries, often takes place on an informal or unregulated basis and in these cases an initial step would be for governments to assist with formalisation and regularisation (i.e. making it simpler for small operations to become legally constituted enterprises).

\section{Gender}

El is typically a male-dominated sector and, in the past, has offered only limited opportunities to women. Encouraging female participation in El requires special attention, which may include the removal of legal barriers to female employment, as well as the provision of appropriate measures, such as maternity leave, childcare, separate changing facilities etc. Furthermore, social investment programmes developed by El companies - in partnership with governments, donors and NGOs - should pay particular attention to the impact of HIVIAIDS upon women and those households left fatherless as a result of the virus.

\section{Post-closure community viability}

Unless careful forward planning is undertaken, regions where El activity has ended may become 'ghost towns'. The problems can be particularly acute when the operations take place in areas that had little or no economic activity prior to an El company's arrival. In such areas, closure of El operations can add to poverty. In addition to the loss of jobs among the local population, public goods and services that may have been provided by the El company cease to be delivered, with particularly harmful effects on the poor and other vulnerable groups.

These problems can occur because of a lack of consensus on who takes responsibility for post-closure economic development. However, in practice responsible companies recognise that an abrupt withdrawal can bring problems for the community and this in turn can create resentment against the company. A good way to avert, or at least mitigate, such difficulties, is for planning to take place well in advance of mine closure. Such planning involves all parties including the national government, local authorities, communities and the El company.

A robust post-closure plan should focus on creating economic diversification during the time of the El activity so that the closure does not represent the withdrawal of the community's only lifeline. This highlights the importance of supporting enterprise development activities to ensure the creation of a competitive and self-reliant local private sector. In addition, the facilities and infrastructure from the El activity can be re-assigned for other commercial or industrial purposes such as tourism, forestry or agriculture. 
2 Regional and Local Impacts

There should also be a transition plan under which the respective legal, financial and institutional responsibilities of the various parties are defined and agreed. This can help to forestall a situation where the government and/or local authorities assume responsibility before they are ready. For example, arrangements should be put in place for the orderly transfer of title relating to housing and other company-constructed buildings that have potential for post-closure usage. 